\title{
Rancang Bangun Pembelajaran Jaringan Server dengan Sistem Server Cloud Virtual (Hypervisor)
}

\author{
Toni Wijanarko Adi Putra ${ }^{1}$ \\ 'Dosen Teknik Informatika - STIMIK ProVisi Semarang, t.wijanarko@gmail.com \\ Jl. Majapahit 304, Semarang, telp/fax : 024-6717201-02
}

\section{ARTICLE INFO}

Article history:

Received 20 Mei 2019

Received in revised form 09 July 2019

Accepted 25 July 2019

Available online 31 July 2019

\begin{abstract}
Computers in the current era have very high capabilities so that they can be used to do virtualization. With computer capabilities that are high enough computer lab practicum and server administration can already be done on a pc or laptop that has virtualization applications installed. Network practicum and server administration that previously could only be done in the classroom then with this technology it is expected that it can be practiced on a PC or personal laptop of each student, so that students are able to continue the practicum scenario that has been given. Virtualization will use Hyper-V that already exists in Windows 7, Windows 8 and Windows 10. In this research Hyper-V will try using 5 Windows servers that are all installed and connected via Active Directory. All windows servers can be accessed using the computer itself or the physical network using the Remote Desktop Connection application. The research will use the SDLC method where each stage will be easily evaluated to get maximum results. This research is expected to be able to prove that computer specifications can at least run virtualization applications with Hyper- $\mathrm{V}$ targeting a minimum of 5 Windows Server applications installed in virtual machines that are connected to each other by network.
\end{abstract}

Keywords: Network, Server, Hyper-V, Remote Desktop

\section{Pendahuluan}

Kemampuan komputer sekarang sudah sangat tinggi [8], mulai dari kecepatan, kapasitas penyimpanan, jumlah kapasitas memory, dan kemampuan prosessor untuk melakukan hyper-threading [9]. Sejalan dengan kemampuan komputer berkembang pula kemampuan aplikasi diantaranya adalah Virtualisasi [10] komputer yang banyak berkembang.

Praktikum Jaringan Server merupakan praktikum yang membutuhkan peralatan komputer dan jaringan kabel [1][2]. Dalam pembelajaran praktikum jaringan server seorang dosen dan mahasiswa tidak akan selesai dalam satu kali pertemuan atau beberapa jam saja, tapi bisa membutuhkan beberapa kali pertemuan. Bisa di bayangkan bila hanya tersedia beberapa ruang lab komputer saja, untuk melakukan praktikum jaringan server menggunakan komputer dan jaringan yang disetting sebagai server dan jaringan sesuai dengan skenario pembelajaran jaringan server. Bila hal ini sudah terjadi maka matakuliah lain yang akan menggunakan ruang lab dan perangkat komputer tersebut tidak akan bisa menggunakannya, karena akan mengganggu konfigurasi yang sudah di susun sedemikian rupa sesuai dengan sekenario pembelajaran jaringan server.

Untuk mengatasi masalah di atas, sistem server cloud virtual (Hypervisor), seperti VMware ESX / ESXi Server [3], Microsoft Hyper-V R2; dan Proxmox Virtual Environ-ment [4], telah mengintegrasikan virtualisasi, mesin virtual, dan layanan virtual. Dengan metode ini, pengguna hanya perlu terhubung ke sistem menggunakan klien berbiaya rendah (PC or PDA atau low-end) untuk menyelesaikan tugas umum, sehingga mengurangi biaya pembelian Teknologi Komputer dan Jaringan.

Received May 20, 2019; Revised July 09, 2019; Accepted July 25, 2019 
Penelitian ini menitik beratkan pada penggunaan aplikasi Virtualisasi yaitu Microsoft Hyper-V yang terdapat dalam paket windows 10 untuk melakukan simulasi pembelajaran jaringan server dengan system server cloud virtual (Hypervisor) [7]. Objek penelitian pada matakuliah Pengelolaan Administrasi Server 1 jurusan Teknik Informatika STMIK ProVisi Semarang.

\section{Landasan Teori}

Secara umum jenis jaringan computer yaitu PAN (Personal Area Network) merupakan jaringan pribadi seperti Bluetooth (keyboard, mouse, headset telepon genggam), LAN (Local Area Network) merupakan jaringan yang terdiri dari beberapa computer yang terhubung dalam satu jaringan, MAN (Metropolitan Area Network) merupakan jaringan yang terdiri dari beberapa komputer atau banyak komputer, yang terhubung dalam suatu jaringan dengan jarak antar kota, dan WAN (Wide Area Network) merupakan jaringan yang terdiri dari beberapa komputer atau banyak komputer yang terhubung dalam suatu jaringan dengan jarak antar benua [8].

Server di beberapa tempat dalam sebuah organisasi besar hanya di gunakan antara 15-20\% dari kapasitas sesungguhnya, sehingga angka tersebut merupakan rasio yang jauh dari edeal. Server sendiri merupakan sebuah komputer dengan prosessor yang mempunyai inti lebih dari satu yang dapat menjalankan aplikasi aplikasi dan services secara bersamaan [9].

Aktif Direktory terdiri atas basis data dan juga layanan direktori. Basis data yang berada dalam aktif direktori menyimpan segala sumber daya pada jaringan [10]. Aktif direktori adalah database terdistribusi dan layanan direktori yang direplikasi diantara semua domain controller pada jaringan. [11].

Microsoft Hyper-V adalah teknologi virtualisasi yang dikemas oleh Microsoft. Awalnya pembelian Virtual PC yang bersamaan dengan peluncuran Microsoft Virtual Server 2005. Virtualisasi terus dikembangkan dan sekarang sudah berubah menjadi Hyper-V. Hyper-V merupakan virtualisasi berbasis hypervisor, sedangkan hypervisor dikenal sebagai virtual machine manager (VMM). VMM sendiri merupakan salah satu dari teknik hardware virtualisasi yang memungkinkan beberapa atau lebih system operasi dapat berjalan dalam sebuah host komputer [12]. Seperti ditunjukkan pada Gambar 1.

\section{Metodologi}

\subsection{Bahan Penelitian}

Bahan penelitian diperoleh dari proses install dengan perangkat keras komputer core i5, hardisk 500Gb, memory 8Gb dengan system operasi Hyper-V pada Windows 10 .

\subsection{Desain Penelitian}

Gambar 1 berikut merupakan arsitektur Hyper-V yang akan digunakan sebagai sekenario penelitian.

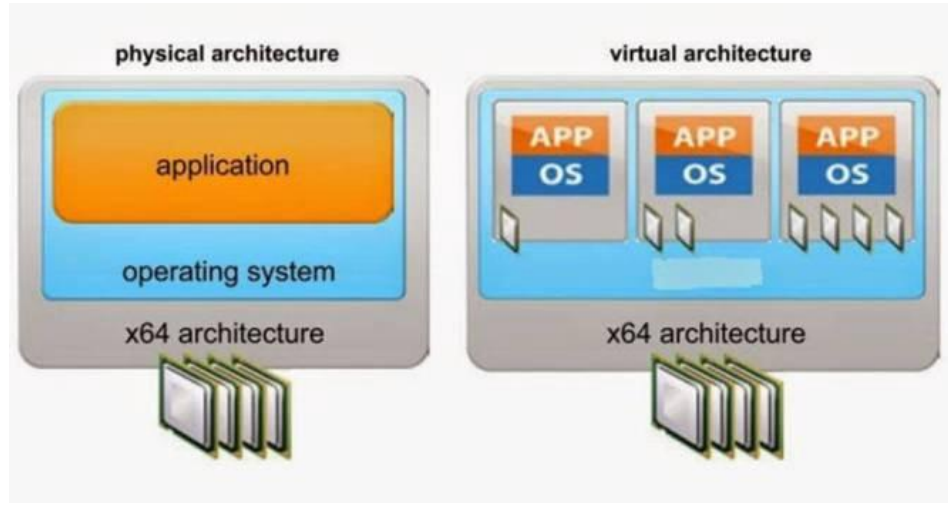

Gambar 1 Arsitektur Hyper-V [15]

\subsection{Perancangan}

Sekenario yang akan di bangun yaitu : Perangkat yang di gunakan meliputi Komputer Core-i5, Harddisk 500Gb, Memory 8 Gb dengan system operasi Hyper-V pada windows 10.

Komponen yang akan diinstall di Hyper-V Komputer (London) yaitu 1. Install Windows Server; 2. Install setup files; 3. Install fonts; 4. Install Macromedia Flash 6.0 Plug-in; 5. Konfigurasi monitor; 6. Install TRANSFORMATIKA Vol. 17, No. 1, Juli 2019: $40-46$ 
Active Directory® service; 7. Konfigurasi keamanan di Active Directory; 8. Install networking services; 9. Konfigurasi DHCP Server Service; 10. Install the Group Policy Management Console; 11. Install Adobe Acrobat Reader; 12. Konfigurasi keamanan alternatif di Active Directory; 13. Membuat GPO dan mengaktifkan pelacakan printer; 14. Mengijinkan membuat GPOs; 15. Penugasan konfigurasi di GPOs.

Sedangkan komponen yang akan diinstall di Hyper-V Komputer (selain London) yaitu 1. Install Windows Server; 2. Konfigurasi monitor; 3. Install Macromedia Flash 6.0 plug-in; 4. Menambah hak akses ke dalam komputer; 5. Install lab files; 6. Install manajemen Group Policy Console; 7. Install Adobe Acrobat Reader.

Untuk Jaringan agar bisa saling terhubung maka perlu mengaktifkan External Network pada Virtual Switch Manager agar semua computer yang terinstall dalam Virtual Hyper-V dapat diakses dari computer diluar computer virtual lewat Koneksi Remote Desktop, seperti ditunjukkan pada rancangan gambar 3.

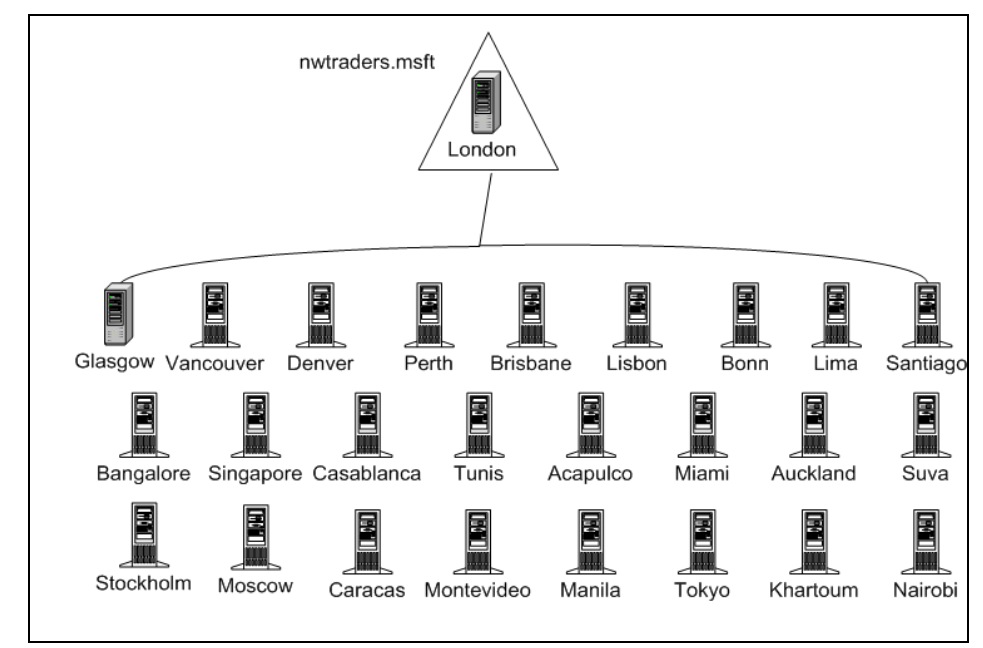

Gambar 2. Sekenario Pembelajaran Jaringan Server

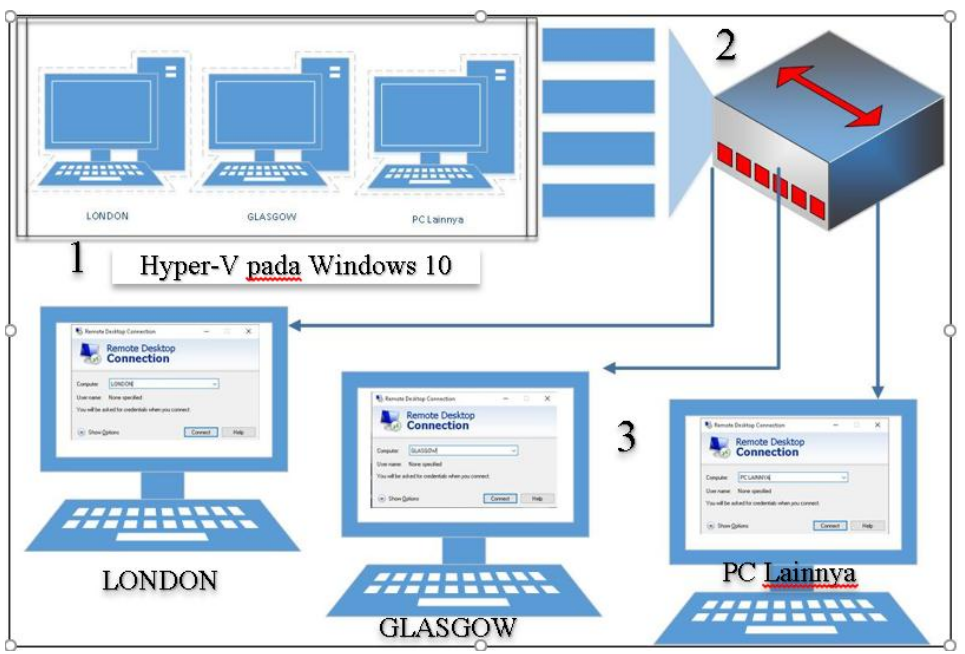

Gambar 3. Rancangan Jaringan

Seperti ditunjukkan pada Gambar 3 terdapat beberapa area, dimulai dari no 1 merupakan gambar yang menunjukkan Hyper-V pada Windows 10, sedangkan no 2 merupakan jaringan fisik berupa swicthub yang menghubungkan antara pc virtual dengan pc fisik, dan no 3 merupakan komputer fisik yang akan mengakses server virtual lewat menu Remote Desktop Connection.

Setelah semua terinstal maka diharapkan semua komputer tersebut akan menjadi satu kesatuan dalam sebuah jaringan server dan bisa digunakan untuk proses pembelajaran. 


\section{Hasil dan Pembahasan}

Hasil dari penerapan perancangan yang dimonitoring pada penggunaan CPU dan memory dengan mengkatifkan sejumlah mesin virtual mulai dari 1 sampai dengan 5, sedangkan pada mesin virtual ke 6 mengalami kegagalan.

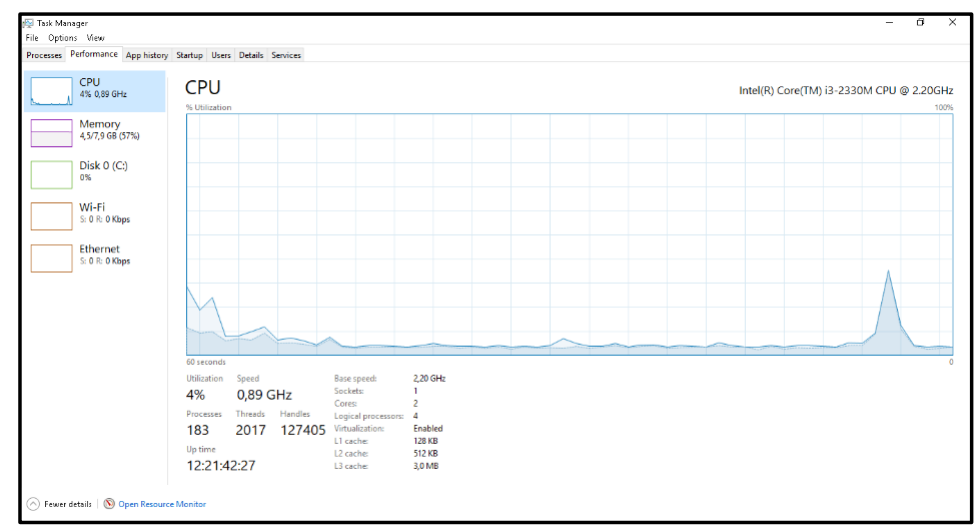

Gambar 4 Grafik Penggunaan CPU dengan 1 virtual server aktif

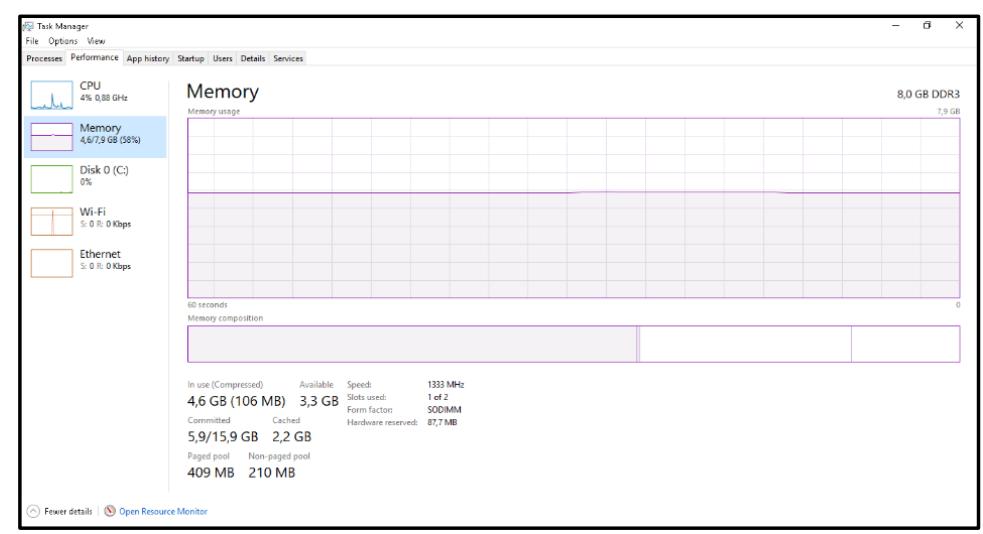

Gambar 5 Grafik Penggunaan Memory dengan 1 virtual server aktif

Seperti ditunjukkan pada Gambar 4 menunjukkan grafik penggunaan CPU pada mesin virtual aktif 1 , sedangkan pada Gambar 5 menunjukkan penggunaan memory. Penggunaan memory tersisa 3,3 GB dari total memory 8 GB.

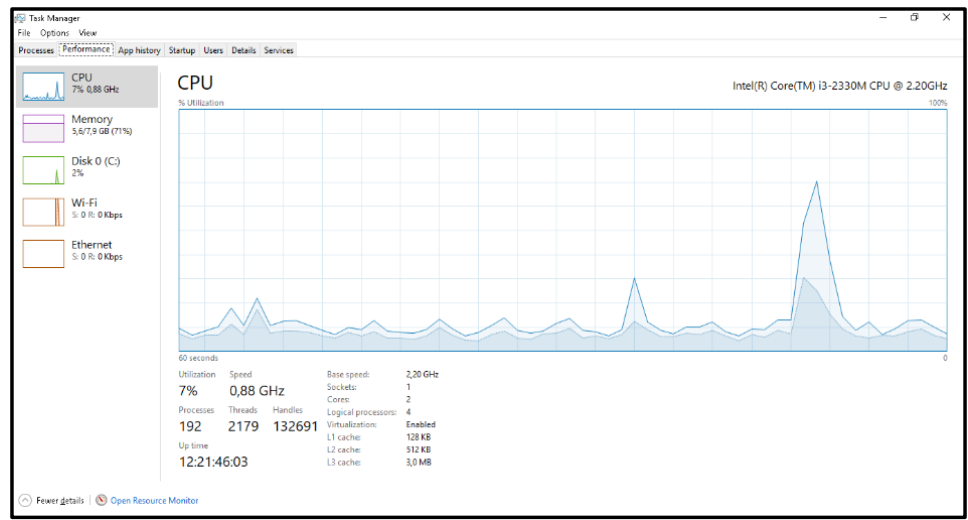

Gambar 6 Grafik Penggunaan CPU dengan 2 virtual server aktif

TRANSFORMATIKA Vol. 17, No. 1, Juli 2019: $40-46$ 
Seperti ditunjukkan pada Gambar 6 menunjukkan grafik penggunaan CPU pada mesin virtual aktif 2, sedangkan pada Gambar 7 menunjukkan penggunaan memory. Penggunaan CPU dan Memory pada penggunaan 2 virtual mengalami peningkatan. Penggunaan memory tersisa 2,5 GB dari total memory 8 GB.

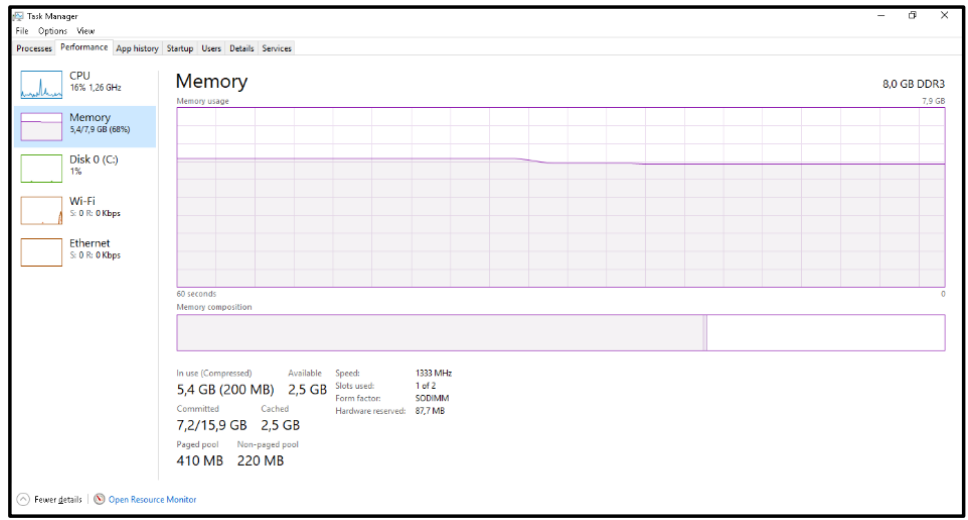

Gambar 7 Grafik Penggunaan Memory dengan 2 virtual server aktif

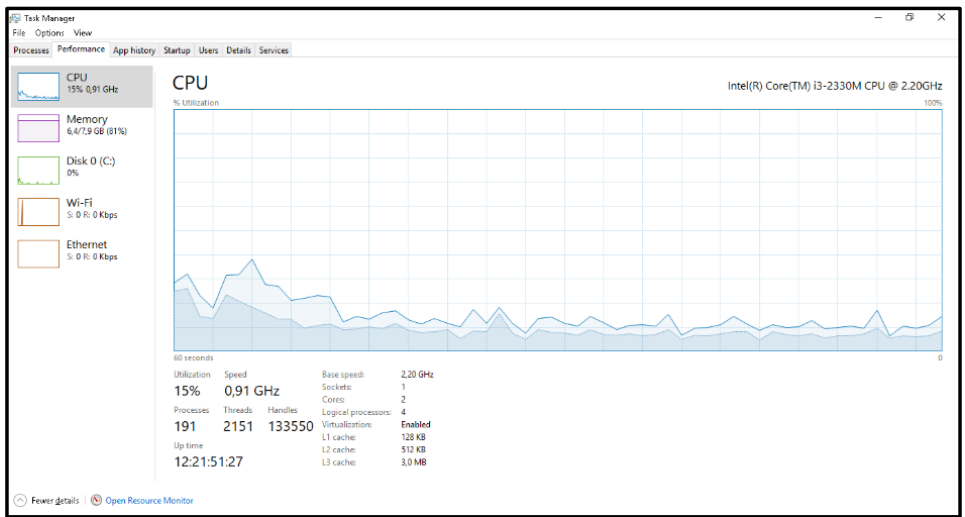

Gambar 8 Grafik Penggunaan CPU dengan 3 virtual server aktif

Seperti ditunjukkan pada Gambar 8 menunjukkan grafik penggunaan CPU pada mesin virtual aktif 3, sedangkan pada Gambar 9 menunjukkan penggunaan memory. Penggunaan virtual sejumlah 3 aktivitas memory sangat kelihatan. Penggunaan memory tersisa 1,6 GB dari total memory 8 GB.

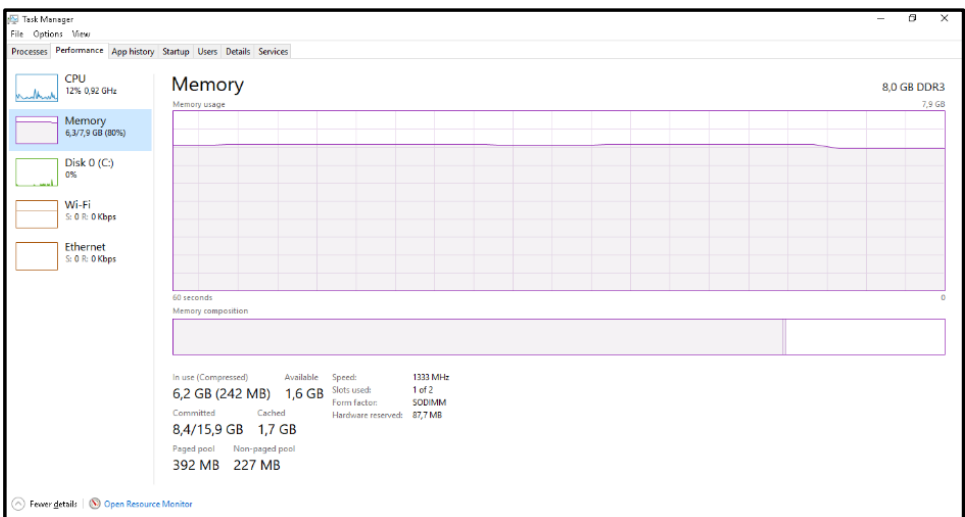

Gambar 9 Grafik Penggunaan Memory dengan 3 virtual server aktif 


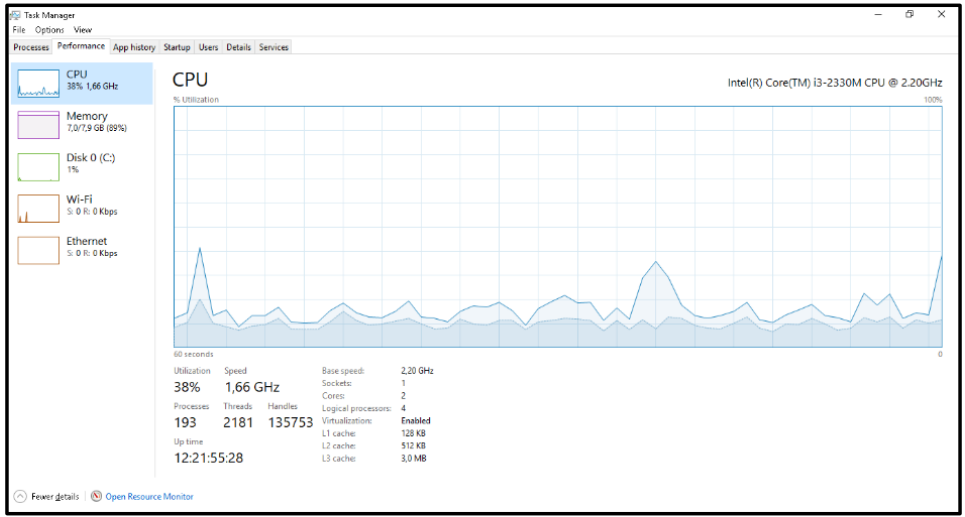

Gambar 10 Grafik Penggunaan CPU dengan 4 virtual server aktif

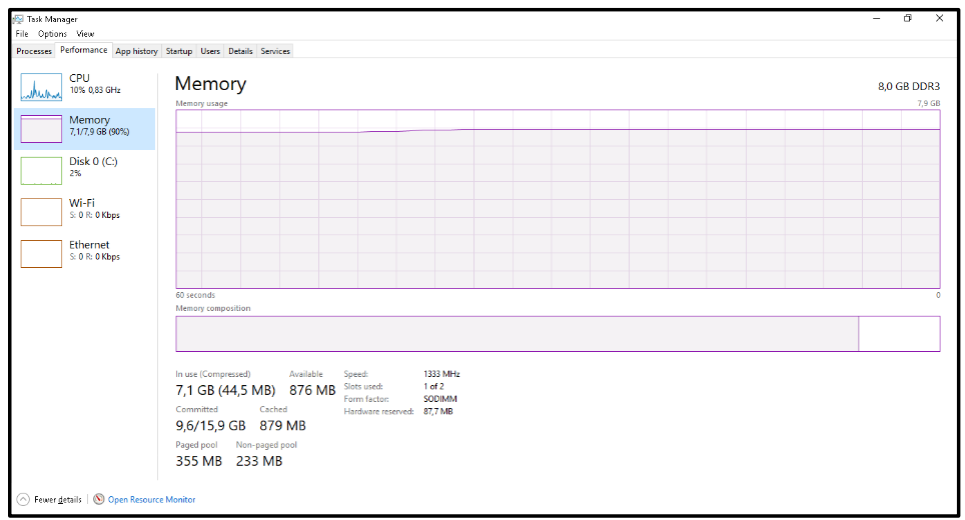

Gambar 11 Grafik Penggunaan Memory dengan 4 virtual server aktif

Seperti ditunjukkan pada Gambar 10 menunjukkan grafik penggunaan CPU pada mesin virtual aktif 4, sedangkan pada Gambar 11 menunjukkan penggunaan memory. Pada penggunaan virtual sejumlah 4 memory sudah mendekati full. Penggunaan memory tersisa $876 \mathrm{MB}$ dari total memory $8 \mathrm{~GB}$.

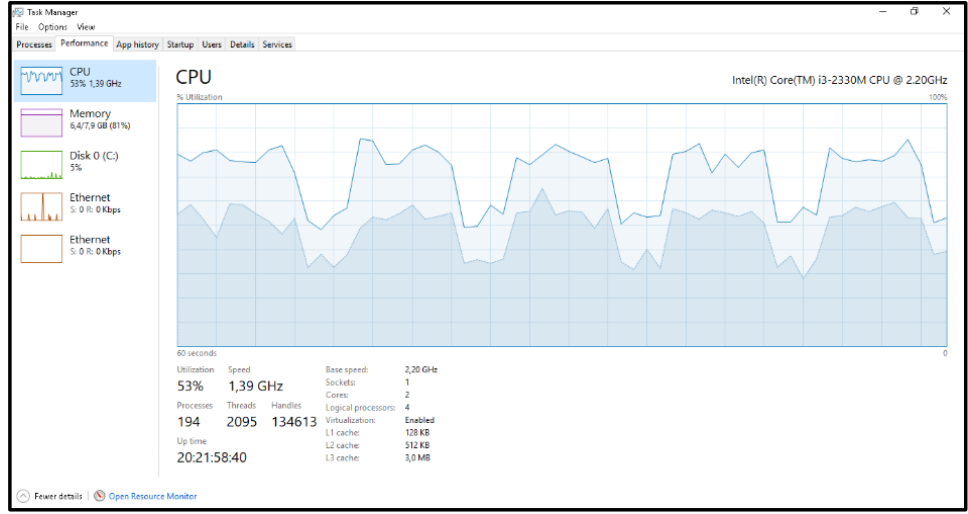

Gambar 12 Grafik Penggunaan CPU dengan 5 virtual server aktif

Gambar 12 menunjukkan grafik penggunaan CPU pada mesin virtual aktif 5, sedangkan pada Gambar 13 menunjukkan penggunaan memory. Penggunaan memory tersisa 697 MB dari total memory 8 GB.

TRANSFORMATIKA Vol. 17, No. 1, Juli 2019: $40-46$ 


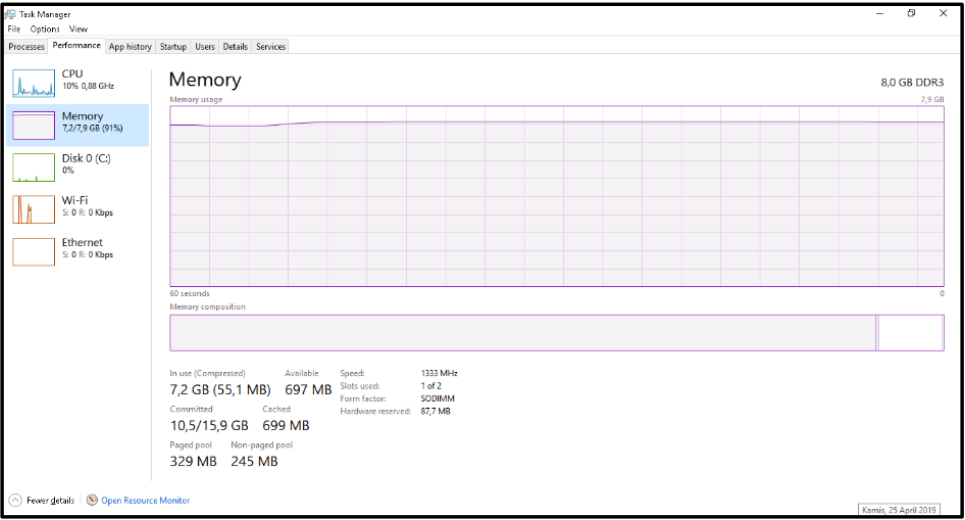

Gambar 13 Grafik Penggunaan Memory dengan 5 virtual server aktif

Gambar13 menunjukkan aktifitas CPU dengan virtual aktif sebanyak 5, sedangkan untuk mengaktifkan virtual mesin ke 6 sudah tidak dapat lagi, dikarenakan memory sudah tidak mencukupi, seperti ditunjukkan pada Gambar 15 .

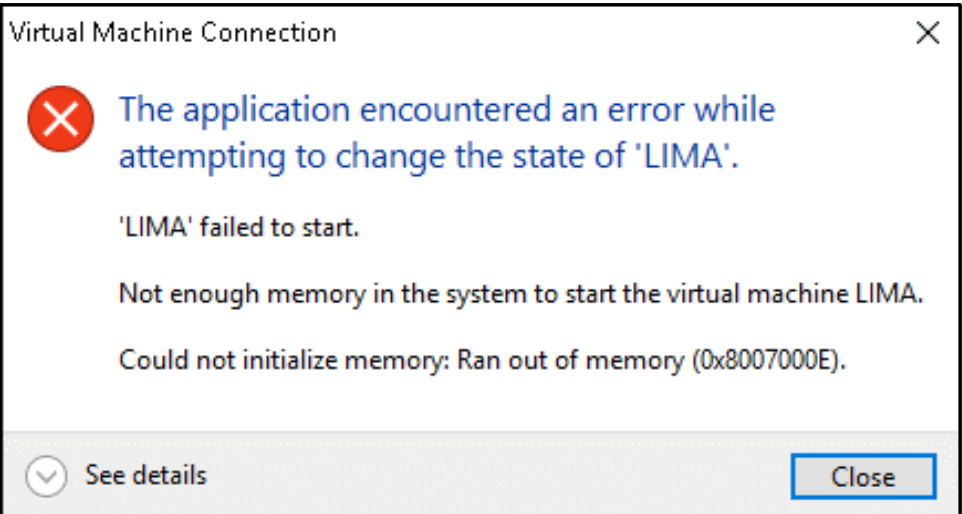

Gambar 15. Kegagalan system saat akan menjalankan virtual server yang ke 6

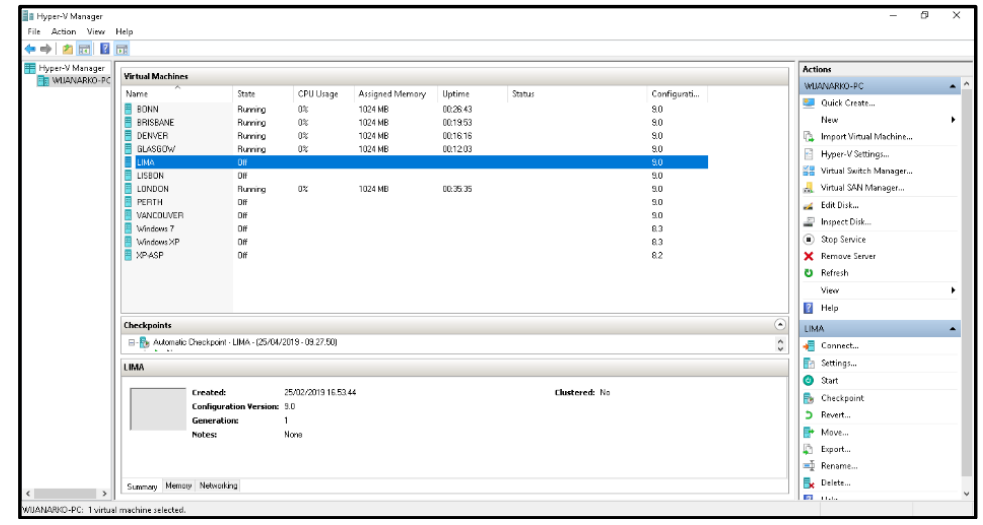

Gambar 16 Jumlah virtual server aktif

Gambar 16 menunjukkan jumlah virtual server yang aktif dilihat dari menu Hyper V Manager, sedangkan Gambar 17 menunjukkan status virtual server yang sudah tidak aktif atau belum diaktifkan. 


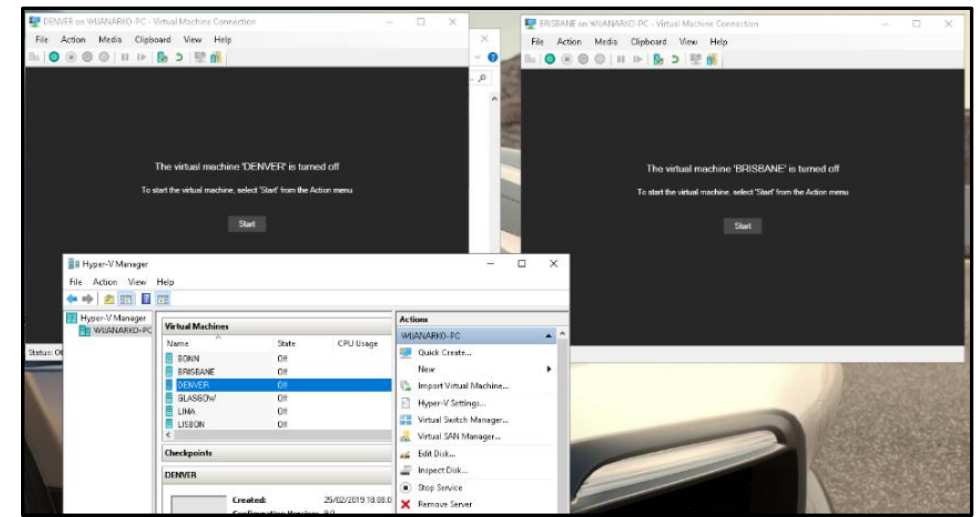

Gambar 17 Tampilan virtual sebelum dinyalakan dan sesudah dimatikan.

Berdasarkan percobaan dan pengujian yang dilakukan dapat di simpulkan bahwa Virtualisasi dapat membantu proses praktikum pada matakuliah yang membutuhkan perangkat pc dan jaringan. Keterbatasan virtual terletak pada kapasistas memory yang terpasang pada Komputer yang di gunakan sebagai server Virtual, dimana untuk setiap mengkatifkan sebuah komputer server virtual akan mengurangi kapasitas memory yang ada.

Tabel 1. Pengukuran Kinerja CPU

\begin{tabular}{cccccc}
\hline CPU & \multicolumn{1}{l}{} & & & \\
\hline Virtualisasi & Utilization & Speed & Processes & Threads & Handles \\
\hline 1 & $4 \%$ & $0,89 \mathrm{GHz}$ & 183 & 2017 & 127405 \\
\hline 2 & $7 \%$ & $0,88 \mathrm{GHz}$ & 192 & 2179 & 132691 \\
\hline 3 & $15 \%$ & $0,91 \mathrm{GHz}$ & 191 & 2151 & 133550 \\
\hline 4 & $38 \%$ & $1,66 \mathrm{GHz}$ & 193 & 2182 & 135753 \\
\hline 5 & $53 \%$ & $1,39 \mathrm{GHz}$ & 194 & 2095 & 134613 \\
\hline
\end{tabular}

Proses CPU dari mulai menjalankan PC Virtual 1 sampai dengan ke 5 tampak pada Tabel 1 bahwa Utilization dan Speed mengalami peningkatan sementara untuk Proscesses, Threads dan Handles tidak terlalu signifikan perubahannya.

Tabel 2. Pengukuran Kinerja Memory

\begin{tabular}{ccrrrrr}
\hline Memory & & & & & & \\
\hline Virtualisasi & In Use & Available & \multicolumn{1}{c}{ commited } & Cached & Page Pool & $\begin{array}{c}\text { Non } \\
\text { PagedPool }\end{array}$ \\
\hline 1 & $4,6 \mathrm{~GB}$ & $3,3 \mathrm{~GB}$ & $5,9 / 15,9 \mathrm{~GB}$ & $2,2 \mathrm{~GB}$ & $409 \mathrm{MB}$ & $210 \mathrm{MB}$ \\
\hline 2 & $5,4 \mathrm{~GB}$ & $2,5 \mathrm{~GB}$ & $7,2 / 15,9 \mathrm{~GB}$ & $2,5 \mathrm{~GB}$ & $410 \mathrm{MB}$ & $220 \mathrm{MB}$ \\
\hline 3 & $6,2 \mathrm{~GB}$ & $1,6 \mathrm{~GB}$ & $8,4 / 15,9 \mathrm{~GB}$ & $1,7 \mathrm{~GB}$ & $391 \mathrm{MB}$ & $227 \mathrm{MB}$ \\
\hline 4 & $7,1 \mathrm{~GB}$ & $876 \mathrm{MB}$ & $9,6 / 15,9 \mathrm{~GB}$ & $879 \mathrm{MB}$ & $355 \mathrm{MB}$ & $233 \mathrm{MB}$ \\
\hline 5 & $7,2 \mathrm{~GB}$ & $697 \mathrm{MB}$ & $10,5 / 15.9 \mathrm{~GB}$ & $699 \mathrm{MB}$ & $329 \mathrm{MB}$ & $245 \mathrm{MB}$ \\
\hline
\end{tabular}

Proses Memory seperti ditunjukkan pada Tabel 2 mengalami perubahan yang sangat signifikan bahkan sampai menyatakan titik maksimal penggunaan PCVirtual, Dihasilkan data perubahan penggunaan Memory dan kapasistas memory tersedia. Pada kolom Commited juga mengalami peningkatansemetara penggunaan cached mengalami penurunan.

TRANSFORMATIKA Vol. 17, No. 1, Juli 2019: $40-46$ 


\section{Kesimpulan}

Berdasarkan percobaan dengan spesifikasi komputer Core i3 dan memory 8 GB dapat menjalankan mesin virtual sebanyak 5 buah dan dalam hal ini untuk praktikum matakuliah Administrasi Server dengan sekenario pada bagian perancangan dapat di praktikkan dengan lancar. Praktikum Administrasi Server pada mesin virtual ini tidak hanya menginstall 5 buah komputer server virtual, tetapi dari kelima komputer server tersebut dapat saling terhubung dengan jaringan aktif directory secara virtual yang masing masing mesin virtual dapat diakses melalui Remote Desktop dari komputer lain lewat jaringan LAN yang ada. Pelu dilakukan penelitian lebih lanjut untuk pemakaian virtual lebih dari 5. Penggunaan komputer dengan spesifikasi yang lebih tinggi lagi.

\section{Daftar Pustaka}

[1] Muhammad T, Zulfin M. Analisis Kinerja Jaringan Komputer di SMK Darussalam Medan dengan Menggunakan Sotfware CISCO Packet Tracer. SINGUDA ENSIKOM. AGUSTUS 2015; Vol.12 No,33: 55-60.

[2] Hartawan I. N. B., Satwika I. K. S., Rancang Bangun Laboratorium Virtual Berbasis Cloud Computing di STMIK STIKOM Indonesia, Jurnal Ilmu Komputer dan Sains Terapan, Jurnal S@CIES Vol. 7 No. 01, Oktober 2016:54-60.

[3] Chang B. R., Tsai H. F., Chen C. M., Lin Z. Y., and Huang C. F., Assessment of hypervisor and shared storage for cloud computing server, Proc. of the 3rd International Conference on Innovationsin Bio-Inspired Computing and Applications, pp. 67-72, 2012.

[4] Kovari A., and Dukan P., KVM \& openVZ virtualization based IaaS open source cloud virtualiza-tion platforms: OpenNode, Proxmox VE, Proc. of IEEE 10th Jubilee International Symposium on Intelligent Systems and Informatics, pp. 335-339, 2012.

[5] Prapanca A, Suartana. I.M., Simulasi Virtual Laboratorium untuk Pengajaran Jaringan Komputer. Journal Information Engineering and Educational Technology, JIEET: Vol. 01 No. 02 2017, ISSN:2549-869X.

[6] Nugraha D.W., Penerapan Kompleksitas Waktu Algoritma Prim untuk Menghitung Kemampuan Komputer dalam Melaksanakan Perintah. Jurnal Ilmoah Foristek Vol.2, No.2, September 2012, P.195-207.

[7] Munjal S., Singla N., dan Sinha N., Hyper-Threading Technology in Microprocessor., International Journal for Research in Applied Science \& Engineering Technology (IJRASET) Vol. 2 Issue X, October 2014, ISSN : 2321-9653, p. 382-384

[8] Harijanto B., Ariyanto B., Desain dan Analisis Kinerja Virtualisasi Server Menggunakan Proxmox Virtual Environment., Jurnal SimanteC., Vol. 5, No.1., Desember 2015, ISSN : 2088-2130, p.17-34.

[9] Rahadjeng I.R., Ritapuspitasari., Analisis Jaringan Local Area Network (LAN) pada PT. Mustika Ratu Tbk Jakarta Timur., Jurnal PROSISKO Vol. 5, No. 1 Maret 2018., eISSN:2597-9922, ISSN: 2406-7733, p:53-60.

[10] Suhendi H., Nurdiyana I., Manajemen Server Jaringan Komputer Berbasis Teknologi Virtualisasi Menggunakan Proxmox., Jurnal Informatika, Vol. 4 No.1, April 2017 p. 130136, ISSN: 2355-6579, e-ISSN: 2528-2247.

[11] Kurnia P.D., Asmunin., Implementasi Aplikasi Manajemen Pengguna dan Grup Berbasis Active Directory Menggunakan Teknologi .NET., Jurnal Manajemen Informatika. Vol.6 No.1 Tahun 2016, p.7-15.

[12] Ruli A.R., Implementasi Active Directory Singgle Domain pada Anak PerusahaanAkita Jaya Mobilindo Jakarta., Seminar Nasional TEKNOKA, Vol.2, 2019, ISSN: 2502-9782, p.103-108. 